\title{
Pareto, Machiavelli, and the critique of ideal political theory
}

Joseph V. Femia

\section{(2) OpenEdition}

1 Journals

Electronic version

URL: http://journals.openedition.org/ress/2554

DOI: $10.4000 /$ ress.2554

ISSN: 1663-4446

Publisher

Librairie Droz

Printed version

Date of publication: 15 December 2013

Number of pages: 133-148

ISBN: 978-2-600-01805-0

ISSN: 0048-8046

\section{Electronic reference}

Joseph V. Femia, "Pareto, Machiavelli, and the critique of ideal political theory », Revue européenne des sciences sociales [Online], 51-2 | 2013, Online since 01 January 2017, connection on 19 March 2020 URL : http://journals.openedition.org/ress/2554; DOI : https://doi.org/10.4000/ress.2554 


\title{
PARETO, MACHIAVELLI, AND THE CRITIQUE OF IDEAL POLITICAL THEORY*
}

\author{
JOSEPH V. FEMIA \\ University of Liverpool \\ femia@liverpool.ac.uk
}

\begin{abstract}
Recent years have witnessed the growing prominence of a "realist" challenge to the prevailing paradigm of normative political philosophy. It is argued that "ideal theory" is fact-insensitive and presupposes conditions that are at odds with the realities of politics. While the "non-ideal" approach to political philosophy presents itself as something new, this article demonstrates, to the contrary, that it originated in the work of Machiavelli, and that it was-in more recent times-developed by Pareto. The cogency of the realist critique of abstract speculation is also demonstrated. Still, political realism remains susceptible to the objection that it rationalises the status quo and offers no basis for systemic change. In response, this article argues that Machiavelli and-especially-Pareto provided the intellectual tools to deal with this objection. Social and political change, in their analysis, can be justified on functional rather than ideal grounds.
\end{abstract}

Keywords: Vilfredo Pareto, Niccolò Machiavelli, normative political theory, realism, functionalism.

Résumé. Au cours des dernières années, la prééminence de la philosophie politique d'inspiration normative s'est vue peu à peu contestée par le paradigme «réaliste». On a reproché à la «théorie idéaliste» d'être insensible aux faits et de présupposer des conditions non concordantes avec les réalités politiques. Alors que l'approche «non-idéaliste» se présente comme relativement nouvelle, cet article entend démontrer qu'elle trouve au contraire son origine dans les écrits de Machiavel et qu'elle fut développée plus récemment par Pareto. Si la pertinence de la critique réaliste à l'encontre des speculations abstraites n'est plus à démontrer, le réalisme politique donne néanmoins prise à la critique en ce qu'il rationalise le statu quo et ne fournit pas d'interprétation convaincante du changement systémique. À cet égard, cet article vise à montrer que Machiavel et, plus particulièrement, Pareto ont forgé des outils intellectuels susceptibles de répondre à une telle objection. II peut en effet être rendu compte du changement politique et social, dans leur analyse respective, sur la base d'une pensée fonctionaliste plutôt qu'idéaliste.

Mots-clés: Vilfredo Pareto, Niccolò Machiavelli, théorie politique normative, réalisme, fonctionnalisme.

* Cet article a précédemment paru dans Joseph V. Femia et Alasdair J. Marshall (eds), 20I3, Vilfredo Pareto: Beyond Disciplinary Boundaries, Farnham (UK), Ashgate, p.73-83. II est réédité ici avec la permission de Ashgate Publishing Ldt. 
For a couple of generations now, the dominant model of political theory - at least in the English-speaking world-has been to formulate ideal principles and concepts, and to assume that these must be expressed in political action. Since this model presupposes "the priority of the moral over the political" (Williams, 2005, p.2), it can be labelled "political moralism". Since its practitioners (Rawls, Dworkin, Raz, Habermas, to name a few) are preoccupied with characteristic liberal themes, such as justice, individual autonomy, human rights, and democratic deliberation, it is sometimes referred to as "liberal moralism". In all its forms, it assumes, in the Kantian tradition, that reason can give us access to a fixed and stable moral order.

A striking feature of this type of theorising is its anti-political bias. As Glen Newey points out, the implementation of rational patterns of life, whatever their content, "would herald the end of politics" (200I, p.7), if by that term we mean the clash of interests and opinions. One is reminded of Marx's view of communism, "the riddle of history solved", a society of perfect transparency and solidarity, where politics in the familiar sense of the word "withers away". Marx realised that the supersession of politics spells the supersession of political philosophy. Normative political philosophers of the present day resemble Marx in their search for a "final solution" to problems of political and social organisation, one that would render further speculation otiose. Even Habermas, who apparently wants to subject us to incessant political deliberation, assumes that universal dialogic procedures or discursive principles, which themselves embody absolute moral commitments, will provide a means of rationally resolving practical discord. The purpose of public debate is merely to endorse decisions generated by reason. The aim of political theory, for Habermas as for other political moralists, is to arrive at a set of ideal prescriptions rather than to justify preferences in the context of existing values and political constraints.

Perhaps inevitably, this reduction of political theory to applied ethics has given rise to a counter-movement of philosophers or theorists who find it insufficiently realistic and insufferably arrogant. The first rumblings of discontent were audible in the late I980s, when Judith Shklar (1989) urged us to substitute a "liberalism of fear" for the more fashionable liberalism of hopes and 
dreams. But the reaction against political moralism has gathered pace during the past decade or so, with an increasing number of theorists challenging the idealistic identification of politics with mankind's most noble aspirations (e.g. Newey, 200I; Williams, 2005; Mills, 2005; Farrelly, 2007; Miller, 2008, and Geuss, 2008). Now of course, Pareto scholars will know that he too was a critic of normative political theory, and that he worked in the tradition of political realism founded by Machiavelli (see Femia, 2006, chs. 4,6). Like the Florentine, Pareto conceived "the political" as a product of the appetitive nature of human beings, and ridiculed theorists who, positing a cosmic purpose or order, dreamt up imaginary republics of ideal virtue, without even the slightest genuflection to things as they are (Pareto, 1935 [1916], §277, §300). In the modern era, Pareto can be seen as the standard-bearer of political realism, which he opposed to the Enlightenment moralising that dominated the political discourse of the eighteenth and nineteenth centuries. Yet the "new realists" do not seem to be aware of his existence. Some of them barely even mention Machiavelli. While they attack liberal moralism for its lack of historicity, their own awareness of the past hardly inspires confidence. But, needless to say, the fact that they are essentially "reinventing the wheel" does not negate the validity of their arguments. In what follows, I want to examine the main criticisms of political or liberal moralism, and to argue that consideration of the attempts by Machiavelli and Pareto to establish political realism can shed light on the strengths and weaknesses of that approach.

\section{THE CRITIQUE}

Realist objections to normative political theory can be divided into four categories. First of all, it is deemed to be descriptively inadequate, insisting on the idealisation of reality "to the exclusion or at least marginalisation of the actual"(Mills, 2005, p.I67). That is to say, it ignores the realities of power and recalcitrant political institutions; it pretends that traditions or economic constraints do not exist, and turns a blind eye to the plurality of values and interests in modern society. Assuming, as did Kant, that politics is the application of a priori principles, discoverable by the exercise of pure reason, it seems 
to be addressed to benign dictators in the Platonic mould who are empowered to enact morally perfect schemes - though no such audience exists in contemporary society. Such criticisms echo Pareto's scorn for what he called "metaphysical" thinking, which tried to demonstrate particular facts by means of general principles, instead of deriving the general principles from the facts. As he described his own theoretical project: "We have no knowledge whatever of what [...] ought to be. We are looking strictly for what is." (1935 [1916], §28). Pareto was unremittingly hostile to the seductive idea that there is something perfect, a realm of Platonic Forms, which contrasts with the imperfect world of experience, and holds out the prospect of political and moral finality. In common with Machiavelli, who wanted to focus on - as he put it - "real truth" rather than "imaginary things" (1975 [I53 I], ch.XV, p.90-9I), Pareto was determined to protect us from the tyranny of abstraction, and to take "experience and observation" as his guide (1935 [1916], §6).

G.A. Cohen (2003, p.243-245) has responded to this strand of criticism by arguing that ideals such as justice are completely independent of facts about human social existence. Principles of justice tell us what we should think, not what we should do. Factual constraints are relevant to the application of such principles, but the principles themselves must remain pure, cleansed of all empirical considerations. However, you do not have to be a Machiavellian realist to wonder whether the validation of moral principles can be independent of all facts. Take the concept of justice. A moment's reflection will tell you that it becomes an issue only in what David Hume called the "circumstances of justice" - scarcity and limited altruism. If both material resources and human compassion were infinite, there would be no need for rules governing the distribution of benefits and burdens. To assume, as does Cohen, that a concept which owes its very existence to factual limitations could be "fact-insensitive" is conceptually incoherent (Farrelly, 2007, p.844-845). Consider another example. Could the moral objection to torture survive if mankind had a much reduced susceptibility to pain? 
This reference to human nature, to the natural human condition, brings us neatly to the second type of criticism levelled at the political moralists: that their theories violate the "ought implies can" proviso and are therefore practically unrealisable. The "motivations that are morally required of us", asserts Thomas Nagel, "must be practically and psychologically possible, otherwise our political theory will be utopian in the bad sense" (1987, p.218). Normative political thinkers tend to ignore this advice. They assume idealised human capacities and pay little or no heed to the limitations of human nature. Cosmopolitan theories of global justice, for example, rely on the prevalence (eventually, if not now) of an almost boundless altruism. Listen to Thomas Pogge, who seems to believe that strangers in distant lands are no less entitled to our beneficent concern than are our closest relatives: "[...] individual human beings are what ultimately matter; they matter equally, and nobody is exempted by distance or lack of shared community from political demands arising out of the counting of everybody equally" (1994, p.86). Similarly, the Habermasian ideal of endless democratic discourse presupposes the availability of almost unlimited time-or at least unlimited willingness to engage in public debate. Both Machiavelli and Pareto, by way of contrast, saw selfishness or egotism as a natural property of the human species. Indeed, the supposed constancy of human nature was what allowed them to discover repeated patterns in history. They poured scorn on all attempts to imagine man as an ideal moral being, and-like the present-day realists-saw no point in judging the real against a vision of perfection.

But here the moralists can enter a plausible objection. Surely moral principles should allow us to criticise agents and practices that fail to conform to them. If we make no demands on the human capacity to make sacrifices for others, or for the common good, if we always assume the worst about human nature, how can we ever discover its limits? However, it is one thing to expect morality to challenge existing thought patterns; it is quite another to make demands that are alien to our deep-seated emotional needs and responses, such as our instinctive valuation of associative duties over those to remote strangers. As David Miller (2005, 2008) has argued, the universalism of normative political theory requires too much of people-to act purely with regard to rational 
considerations, to abstract oneself from all social particularity and become a citizen of nowhere, an impartial actor. There is the danger of slipping into a kind of absolutism, where-in the words of C.A.J. Coady - the "morally advisable becomes the morally obligatory, or the somewhat morally preferable becomes a stern duty" (2008, p.I7). The purveyors of such absolutism, it could be argued, condemn themselves to moral irrelevance. A deontological ethic (I have Cohen in mind) in which the definition of what is right is not derived from a calculation of what is possible would oblige us to hold (oddly) that certain actions are morally obligatory even though no one, or hardly anyone, can be expected to perform them. Of course, this argument could be pushed too far. By definition the ideal stands in opposition to the real, and not even Machiavelli and Pareto wanted to deny that we could aspire to something better than the status quo. Moreover, the present unrealisability of an ideal does not show that it is unrealisable tout court. Slavery was once seen to be an entrenched part of the natural order, and those who opposed it were dismissed as idealistic visionaries. While there is no disputing such considerations, it is generally understood that moral thinking must pay attention to possibility and feasibility if it is to avoid destructive outcomes.

This brings us to the third type of criticism levelled at political moralism: that attempts to implement ideals, however admirable these ideals might seem, can lead to unintended and unwelcome consequences. The main problem here is the alleged mismatch between natural human behaviour and the requirements of the ideal. Machiavelli expressed this point with brutal clarity in chapter I5 of The Prince, where he issued a warning to all "well-meaning" statesmen: "[...] the gulf between how one should live and how one does live is so wide that a man who neglects what is actually done for what should be done learns the way to self-destruction rather than self-preservation." (I975 [I53I], p.9I). Pareto, defending Machiavelli against the charge of immorality, points out how hard it is to get people to face inconvenient political facts: "Anyone viewing the facts objectively, anyone not minded deliberately to shut his eyes to the light, is forced willy-nilly to recognize that it is not by being moralists that rulers make their countries prosperous." If anyone is to blame for this unpleasant truth, it is not the rulers but “"corrupt' humanity” (Pareto, I935 [1916], §1975, §24I0). 
But those who are enamoured of normative ideals are not only accused of harbouring illusions about the powers and capacities of ordinary people and ordinary politicians; they are also berated for ignoring empirical constraints and competing ideals. In Machiavellian fashion, the critics draw attention to the paradox that virtues can become vices in a political context. It is not sufficient, they say, for philosophers to evaluate an ideal itself, in all its pristine purity; we must also assess the likely or necessary moral costs of the changeover to the supposedly ideal system. In Pareto's words, we should “consider both the intended and the incidental effects" (ibid., §ı864). Certain ideals should be rejected, not only if it is literally impossible to implement them, but also if in practice it would be too costly in terms of values we hold dear. According to J. Raikka:

Kant and his followers are wrong in claiming that only social arrangements that are impossible to carry out are infeasible. When evaluating the feasibility of a social institution, it is not enough to consider the strong constraints. Indeed, a political theorist should consider some of the weak constraints too, namely those that entail moral costs if the suggested institutional arrangements are implemented (Raikka, I998, p.37).

On this argument, even when a morally desirable ideal is infeasible only in the weaker sense, the morally correct approach would be to counsel compromise. Ignoring Voltaire's famous aphorism that "the best is the enemy of the good" could produce an outcome that makes the status quo seem attractive.

This argument is open to challenge, however, since it assumes that political philosophers can accurately predict the costs of changing social arrangements, and in all circumstances. Political scientists, let alone political philosophers, find it difficult to make such predictions; and in any case-say the defenders of normative theory - the evaluation of social ideals should be distinguished from the evaluation of policies designed to implement those ideals (O’Neill, I988). This is true to a degree, but our accumulated human experience does provide solid evidence of the unwanted consequences that can be generated by pursuing certain ideals. The complexity of social causation need not reduce us to cognitive helplessness. While the twentieth century experiment in communism is an obvious example, there are other, less dramatic 
ones. We now know, for instance, that our high-minded efforts to aid poor individuals and countries can result in debilitating cycles of dependency. For a political philosopher simply to ignore such considerations when devising an ideal scenario would seem to be remiss, given that they appear to be grounded in unavoidable economic and administrative imperatives, and in permanent patterns of human motivation. An "ideal" theory is hardly ideal if its implementation will almost certainly entail significant moral costs.

It could be argued, however, that this "realist" argument is based on a narrow understanding of the functions served by universal ideals. Furnishing a blueprint for radical change is only one such function. As John Rawls (I999, p.216) has argued, an ideal conception gives us a standard by which to measure reality. How could we ever use the term "unjust" unless we had an ideal standard of justice to guide our judgement? This is an unconvincing argument. In order to identify individual cases of injustice, we need possess only a loose principle of fairness, which need not aspire to universality or timelessness. It may simply be inherent in the habitual practices of our society. How many people feel the necessity to consult an ideal political philosopher before making such judgements?

We therefore come to the fourth and final criticism of political moralism: that it lacks an historical perspective and shows no understanding that moral vocabularies will necessarily vary over time and space (e.g. Williams, 2005, p.r3). When it comes to morality, realists are cognitive pessimists, who doubt that such a thing as "truth" exists or is usefully accessible to human intelligence. Political concepts, they tend to believe, are subject to competing interpretations and historical changes of meaning. It follows that the quest for an Archimedean point, removed from any context, is futile. In its Marxist, or postmarxist, form, this perspective goes so far as to accuse the liberal moralists of being bourgeois ideologists, reflecting in their ideas and values the interests and experiences of their own class. To Mills, their social ontology "will typically assume the abstract and undifferentiated equal atomic individuals of classical liberalism". This ontology is oblivious to the "relations of structural domination" that profoundly shape the thought and behaviour of all social agents. The hypostatised individual that dominates the discourse of liberal political philosophy, 
that "natural" possessor of rights and freedoms, that exemplar of rationality, is nothing but a false universal, a mental construct, detached from the hegemonic ideologies and group-specific experiences that distort our perceptions of the social order (Mills, 2005, p.168-172).

But one can reject the "spurious universalism" (ibid., p.i73) of normative theory without endorsing class analysis and all its attendant intellectual baggage. Pareto, for his part, insisted on the inevitability of historical and cultural variation in the normative content of political concepts. Like Machiavelli and other realists, he was hostile to "essentialism" and to the assumption that "logic" and "reason" could or should dictate human behaviour (Pareto, 1935 [1916], §69, §300, §47I). For him, ethical standards were not universal and rational truths but historically conditioned products of changing circumstances and shifting passions. The idea that such standards had a purely "logical" foundation was antithetical to his account of human psychology, which assumed that "sentiments", or-in his distinctive jargon- "residues", determined our behaviour, and that what we call rational judgement was merely an exercise in ex post facto justification for instinctive preferences (ibid., §359). For example, when a person says “That thing is unjust" what he really means, according to Pareto, is "that the thing is offensive to his sentiments" (ibid., §ı210). These psychic states (sentiments/residues) were, in Pareto's opinion, more or less universal responses, but their theoretical expression-belief systems or "derivations"-varied according to context. From a Paretian perspective, then, the contractarian theory of Rawls would be dismissed as "essentialist" or "metaphysical" in its assumption of an objective idea of justice, floating above all historical and cultural particularities. Pareto was a critic of contract theory, seeing it as a bogus and futile attempt to escape temporal criteria of judgement (ibid., §.I I46, §I504-I507). For him, political categories such as "justice" are functional rather than objective-serving both psychic and social needs. They can never achieve closure since their content-unlike their underlying motivation-is culturally determined (ibid., §1893). Pareto's argument finds an echo in those critics of Rawls - often cultural relativists - who maintain that his theory of justice is nothing more than a liberal theory of justice, reflecting the outlook of comfortable American professors. 
Rawls and other normative theorists might object that such criticisms confuse questions of origin with questions of validation. The existence of historical and cultural diversity does not rule out the possibility that one single idea or ideal is indeed the true one, with the rest being impostors. Well, perhaps-but the liberal idealists scrupulously avoid any reference to God or Revelation. In the absence of divine intervention, what mysterious factor or attribute has allowed them to overcome the cultural limitations that have afflicted all previous thinkers, and to arrive at the one true concept of humanity? Pareto was contemptuous of such pretentions. In his view, even if abstract moral absolutes did exist, we could never discover what they are, as they correspond to "nothing real", nothing tangible (ibid., §I55 I). Except in the realms of logic and mathematics, we cannot demonstrate the truth or existence of what we cannot observe, or reduce to a set of identifiable empirical operations, performances, or capacities. For Pareto, as we have seen, abstract concepts such as "justice" are used to designate specific situations that agreeably stimulate our sentiments (ibid., §ı210, §ı609). Yet normative philosophers persist in their tortuous efforts to "prove" that the term refers to some objective reality that is not immediately evident to the senses. Pareto offers a psychological explanation for this otherwise puzzling "delusion":

A person living in a civilised society becomes familiar with certain moral or juridical relationships that are continually shaping his life, with which his mind is gradually saturated, and which end by becoming part and parcel of his intellectual personality. Eventually, through group-persistences, through his inclination to take what is relative as absolute, he carries them beyond the limits within which they may have been valid. They were adapted to certain circumstances, certain cases, merely; he makes them serve all cases, all circumstances. So concepts of an absolute morality and an absolute law come into being (ibid., §I5OI).

Pareto believes that the "residue" of "sociality" plays an important role here (ibid., §I429). If a person reading a poem exclaims, "It is beautiful”, he really means that it seems beautiful to him. Given our social/imitative nature, however, anyone hearing the exclamation will feel that the poem ought to make a similar impression of beauty upon him. And so on and so forth. What was originally a subjective preference is transmuted into an "objective" fact. The perception grows that the poem is beautiful, no matter what people may think of it. 


\section{TOWARDS A REALIST ALTERNATIVE}

Even if we accept, as I do, that the realist criticisms of political or liberal moralism are convincing, this does not necessarily mean that realism constitutes a viable alternative. Is it really possible, as Machiavelli and Pareto apparently claimed, to have a purely empirical political theory, one that only explores (as the Florentine put it) "what is actually done", not "what should be done" (1975, ch.XV, p.9I)? Are normative preferences not built into our descriptive language? Do our factual claims not often have an evaluative element? When we describe the glass of water as either half empty or half full, are we not making a kind of value-judgement? Of course, we could simply say that a realist theory of politics should be primarily descriptive, even if it cannot avoid normative content altogether. When Pareto (1935 [1916], §365) writes that it is "not the function of theory to create beliefs", he means that theorists should not presume to develop visions of the good society. It is not a logical corollary that they should eschew any hint of evaluation in their theoretical analyses. But there is a further question. Assuming it is possible, is it actually desirable to avoid direct consideration of "what ought to be"? Are we really willing to renounce the idea of a political "good" that transcends the actual, and to define politics as nothing more than the struggle for power and advantage? As Rawls has pointed out, "the limits of the possible are not given by the actual" (I999, p.I2). Not without reason, the realist outlook is routinely lambasted for reifying the present by identifying existing arrangements with abstract necessity.

Despite their frequent professions of perfect scientific impartiality, neither Machiavelli nor Pareto rejected all normative claims. Although they offered no explicit conception of "the good", nor any notion of the ideal arrangement of society, they both expressed clear political preferences. The former thinker defended the virtues of republican governance and called for the expulsion of foreign forces from the Italian peninsula; the latter was a champion of free market principles. Rather like Marx, however, they saw these preferences as emerging, almost naturally, from their empirical observations. When discussing Machiavelli, Antonio Gramsci-Marx’s most eminent Italian disciple-reminded us that hostility to abstract universals does not necessarily exclude normative 
aspirations, as long as these originate in real, observable social trends, and not in "idle fancy, yearning, daydream". Far from being a Kantian moral imperative, the "ought-to-be" is, properly conceived, a projection of forms and principles inherent in existing reality (197 I [1929-1935], p.I30, p.I72). Gramsci is not saying that values can be logically deduced from facts about the world; he is simply saying that political values and goals should have a factual, as opposed to speculative, basis. It seems to me that the normative preferences expressed by Machiavelli and Pareto satisfy this criterion. In their writings, we can find the outline of a "realistic" political theory that can nevertheless transcend the present and fulfil the natural human desire for improvement. The theorist, on this conception, immerses himself in "what exists" in order to change society. But why does the realist thinker want to change society? After all, he disparages the doctrinal liberal for seeking to eradicate the mysteries of the human world by substituting for them the certainty of applied reason. The answer perhaps lies in what is, for political realism, the primary political objective: namely, the establishment of order and the conditions for cooperation. To most realists, the requirements of good order will not remain static. Because of the appetitive and competitive nature of human beings, order is precarious and susceptible to being undermined by any of the infinite variety of life's contingencies. Given this existential instability, given this assumption that transience is part of the human condition, the maintenance of a balance of mutual advantage will often entail the need for innovation. Ought propositions, in other words, would be fundamentally determined by the struggle for power, and not by a desire to impose timeless moral truths.

In defence of this position, Gramsci refused to accept a dichotomy between realism and idealism (ibid., p.I72): "The opposition between Savonarola and Machiavelli is not an opposition between what is and what ought to be [...], but one between two concepts of what ought to be: the abstract and phantasmagorical concept of Savonarola, and the realistic concept of Machiavelli". Machiavelli was keen to mobilise the Italian people for progressive ends-ultimately, the creation of a unified national state. But, to him, these ends were not imaginative constructs or logical deductions from first principles. To the contrary, they were practical aspirations, grounded in objective historical 
forces. Gramsci, in his attempt to explain the nature of Machiavelli's project, distinguished between two types of realism: one wishes only to "manage" the status quo, to preserve the existing configuration of power; the other is willing to pursue a radical agenda, since it views empirical reality not as "something static and immobile", but as "a relation of forces in continuous motion" (ibid.). Gramsci saw his own thought (and Marxism in general) as exemplifying this "transformative" type of realism, whose origin he attributed to Machiavelli.

Pareto, too, maintained that the social system is "constantly changing in form” (1935 [1916], §2067). It is "never at perfect rest", he informs us; "it is in a perpetual state of becoming" (I966 [192I], p.299). While he focuses on social equilibrium, it is a dynamic equilibrium, analogous to that of a living organism, not one defined by coexisting properties in a static system (1935 [1916], §2072). It was mentioned earlier that realists could advocate change as a way of preserving social order in the face of instability. The richness of Pareto's analysis allows us to explore this idea in greater depth. By way of preliminaries, let us bear in mind that realism, in the Machiavellian sense, is not just about practicality; it also involves the uncovering of hidden truths (motives, power relations, perverse consequences) lurking beneath the veneer of pieties and platitudes that sustains the status quo. The realist typically wants to lift the veils of euphemism and portray social and political life as it really is, without embellishment. In this sense, the realist, even if he veers to the right, is never conventionally conservative; he is alive to the contingencies and dysfunctions of society, and-at least in the cases of Machiavelli and Pareto-takes pleasure in pointing them out. Even if we remove Marxist "realists" from the equation, the realist mind-set is potentially, if not actually, subversive; its attachment to "what is" smacks of conditionality. The underlying structural reality of society may point in a different direction from its professed values and objectives. In Pareto's equilibrium theory, the fundamental reason for such a discrepancy might lie in economic development, which often requires a corresponding change in the collective psychology or thought-processes of society in order to restore stability (ibid., §2340). As a realist, Pareto was hostile to change that originated in abstract theoretical schemes or in what he dismissed as "sermo- 
nizing" (ibid., §2016). Such change he described as "artificial” rather than "normal" (ibid., §2067-2068), for it is disconnected from observable social trends. His equilibrium model is broadly "functionalist" in the sense that actions, whether individual or collective, are "selected" by their functional consequences. In his phrasing: "It is a matter of selection, the choice being dictated by the nature of the system” (ibid., §2268). What is functional at one time may not be functional at other times. Changing circumstances (not just economic change, but also events such as defeats in war or political upheavals) may cause a "normal" disturbance to the social balance. Existing modes of belief and political behaviour may appear "at odds with reality" and therefore unsustainable in present form. A "society which is not eager to decline or perish must necessarily reject them” (ibid., §2340).

Those who approach society from a broadly functionalist and realist perspective will not always converge on the identification of dysfunctions or on their solution. A Marxist like Gramsci will stress the supposed contradictions of capitalism, along with their resolution in a form of radical socialism. Pareto, a staunch defender of capitalism, would hardly agree. It should be clear by now that a realist analysis cannot entirely detach itself from value preferences. As Gramsci recognised, however, there is no contradiction here. Such preferences are compatible with realism provided that they are embedded in society and do not express mere "yearning" or "daydream". Of course, patterns of thought and behaviour in any modern society are complex and variable. Deciding which potential changes are "intrinsic" and which are-in Pareto's parlance - "artificial” will inevitably involve a large degree of subjectivity-and this indeterminacy could be seen as a weakness. But what I think I have shown is that political moralism, with its exclusively normative concerns, does not enjoy a monopoly of political morality. Those who reject the abstract idealism of Anglo-American political philosophy are not thereby condemned to act as apologists for the status quo. And in their search for guidance in these matters, they would do well to consult the teachings of Machiavelli and Pareto. 


\section{BIBLIOGRAPHY}

COADY C.A.J., 2008, Messy Morality: the Challenge of Politics, Oxford, Clarendon Press.

COHEN G.A., 2003, "Facts and Principles", Philosophy and Public Affairs, 31-3, p.21 I-245.

FARRELLY C., 2007, “Justice in Ideal Theory: a Refutation”, Political Studies, 55-4, p.844-864.

FEMIA J.V., 2006, Pareto and Political Theory, New York and Abingdon, Routledge.

GEUSS R., 2008, Philosophy and Real Politics, Princeton, Princeton University Press.

GRAMSCI A., I97I (1929-1935), Selections from the Prison Notebooks, London, Lawrence and Wishart.

MACHIAVELLI N., 1975 (I53I), The Prince, Harmondsworth, Penguin.

MILLER D., 2005, "Against Global Egalitarianism”, The Journal of Ethics, 9- I, p.55-79.

-, 2008, "Political Philosophy for Earthlings", in Political Theory:

Methods and Approaches, ed. by D. Leopold and M. Stears, Oxford,

Oxford University Press, p.29-48.

MILLS C., 2005, '“Ideal Theory' as Ideology”, Hypatia, 20-3, p.165-184.

NAGEL Th., 1987, "Moral Conflict and Political Legitimacy", Philosophy and Public Affairs, 16, p.215-240.

NEWEY G., 200I, After Politics: the Rejection of Politics in Contemporary Liberal Philosophy, Basingstoke, Palgrave.

O'NEILL O., 1988, "Abstraction, Idealization and Ideology in Ethics", in Moral Philosophy and Contemporary Problems, ed. by J. D. G. Evans, Cambridge, Cambridge University Press, p.55-69.

PARETO V.,1935 (1916), The Mind and Society, 4 vols, New York, Harcourt, Brace and Co. -, 1966 (1921), "Trasformazione della democrazia", in Sociological Writings, Oxford, Basil Blackwell, p.299-325.

POGGE Th., 1994, "Cosmopolitanism and Sovereignty", in Political Restructuring in Europe: Ethical Perspectives, ed. by C. Brown, London, Routledge, p.85-1।8. 
RAIKKA J., 1998, "The Feasibility Condition in Political Theory", The Journal of Political Philosophy, 6-I, p.27-40.

RAWLS J., 1999, The Law of Peoples, Cambridge, Mass., Harvard University Press.

SHKLAR J., 1989, "The Liberalism of Fear", in Liberalism and the Moral Life, ed. by N. Rosenblum, Cambridge, Mass., Harvard University Press, p.2I-38.

WILLIAMS B., 2005, In the Beginning was the Deed: Realism and Moralism in Political Argument, Princeton, Princeton University Press. 